\title{
Desenvolvimento de Suco Misto com Característica Cítrica
}

\author{
Endy Camile de Noronha (I), Gilson Parussolo (I), Mônica Turchetto \\ (I), Rafael Porto Ineu (I) \\ (I) UFSM - Universidade Federal de Santa Maria (Linha Sete de Setembro, s/n, CEP: 98400- \\ 000, Frederico Westphalen, RS, Brasil)
}

\section{Resumo}

O consumo de sucos de frutas processados vêm aumentando pela praticidade que esses produtos oferecem e por serem considerados mais saudáveis do que bebidas carbonatadas. A produção de bebidas mistas pode ser realizada para complementar os nutrientes fornecidos por diferentes vegetais e obtenção de novos produtos. O objetivo deste trabalho é avaliar a qualidade microbiológica e físico química de quatro formulações de suco misto, para verificar sua adequação aos padrões e normativas à este tipo de produto. Foram elaborados quatro formulações diferentes de sucos mistos, e cada formulação contou com a adição de três frutas, na proporção de $20 \%$ cada, sendo elas laranja, bergamota e maracujá no suco misto A; laranja, bergamota e abacaxi no suco misto $\mathrm{B}$; bergamota, maracujá e abacaxi no suco misto C; e laranja, maracujá e abacaxi no suco misto D, com proporção final de $60 \%$ de suco concentrado e $40 \%$ de água. Os sucos concentrados foram batidos em liquidificador com água e 4\% de açúcar, posteriormente filtrados, acondicionados em garrafas plásticas e armazenados à aproximadamente $4^{\circ} \mathrm{C}$. As amostras foram submetidas à análise microbiológica para detecção de presença de coliformes. As análises físico químicas foram de $\mathrm{pH}$, sólidos solúveis e acidez titulável em $\%$ de ácido cítrico. A contagem de coliformes totais, para todas as amostras, apresentou-se negativa, estando dentro dos padrões legais, mantendo a qualidade para a comercialização e consumo, sem oferecer danos à saúde. As amostras ficaram com o pH entre 3,9 e 4,3, revelando que a formulação sem bergamota (SMD) ficou mais ácida e a sem maracujá 
(SMB) menos ácida. A acidez titulável ficou entre $0,57 \%$ e 0,76\%, indicando novamente as formulações SMD com maior e a SMB menor porcentagem. Os graus brix ficaram entre $8^{\circ}$ e $9^{\circ}$. Não há um regulamento específico para sucos e néctares mistos na Legislação Brasileira, portanto toma-se como base as normas que regulamentam as bebidas e sucos em geral, verificando-se portanto, que a acidez total titulável ficou dentro dos padrões, e apenas os sólidos solúveis ficaram um pouco abaixo do padrão para sucos adoçados, provavelmente pela baixa quantidade de açúcar adicionado nas formulações. Pode-se concluir então, que o produto apresentou-se seguro para o consumo da população e, mesmo sem legislação específica, teve bons resultados quanto as suas características físico químicas.

Palavras-Chave: Qualidade, Coliformes totais, Acidez Titulável Agência de Fomento: 